\title{
Doppler ultrasonographic studies of the uterine blood flow in mares
}

\author{
Uta Blaich'1, Svenja Petzold', C.P. Bartmann', K. Lorber', H.-A. Schoon², Gerit Raila² and H. Bollwein ${ }^{3}$ \\ 1 Klinik für Pferde der Tierärztlichen Hochschule Hannover, Germany \\ 2 Institut für Veterinär-Pathologie der veterinärmedizinischen Fakultät, Universität Leipzig, Germany \\ 3 Gynäkologische und Ambulatorische Tierklinik der Ludwig-Maximilians-Universität, München, Germany
}

\begin{abstract}
Summary
The uterine arteries of ten mares, from which endometrial biopsies had been taken and graded from category I to category III, were investigated on a daily basis for an entire cycle using transrectal Doppler ultrasonography. All mares showed a similar cyclic variation in uterine blood flow. Resistance to blood flow in the uterine artery was highest in the periovulatory period. The mares of category IIb and III (group B) had higher values of uterine artery impedance when compared to those mares in category I to lla (group A). Some of the mares in group B showed an absence or reverse in diastolic blood flow. These results agree with similar data obtained in women, where there is discussion as to whether reduced uterine blood flow can cause infertility.
\end{abstract}

keywords: $\quad$ mare, Doppler ultrasound, uterine artery blood flow, estrous cycle, endometrosis

\begin{abstract}
Dopplersonographische Studien zur hämodynamischen Uterusperfusion bei der Stute
Die Arteriae uterinae von zehn Stuten, deren Endometriumsbiopsien in die Kategorien I bis III eingestuft waren, wurden transrektal mittels Doppler Ultrasonographie täglich über einen Zyklus untersucht. Alle Stuten zeigten ähnliche zyklische Schwankungen der uterinen Durchblutung. Der höchste Widerstand der Uterinarterie trat in der periovulatorischen Phase auf. Die fünf Stuten der Kategorien III und III (Gruppe B) wiesen insgesamt einen größeren Gefäßwiderstand, verglichen mit den Stuten der Kategorien I bis Ila (Gruppe A), auf. Einige Stuten der Gruppe B zeigten einen fehlenden oder rückläufigen diastolischen Blutfluß. Diese Ergebnisse stehen im Einklang mit denen bei der Frau, bei der eine verminderte uterine Durchblutung als mögliche Ursache von Infertilität diskutiert wird.
\end{abstract}

Schlüsselwörter: Stuten, Doppler Ultraschall, uteriner Blutfluß, Zyklus, Endometrose

\section{Introduction}

Degenerative changes in equine intrauterine blood vessels were first reported by Kenney in 1978. Further detailed pathohistological studies have shown angiopathies to be a common finding on biopsy of the equine endometrium (Schoon et al. 1994; Kriesten 1995; Grüninger 1996 and Schoon et al. 1997). Angiopathies as a cause of decreased uterine perfusion have been discussed and may be responsible for, or contribute to the development of endometrosis (Grüninger 1996).

Transvaginal Doppler ultrasound is a technique routinely used to examine blood flow in the uterus of women. In human medicine the use of Doppler ultrasound as an aid in infertility diagnostics was first described by Goswamy and Steptoe (1988). They suggested that abnormal uterine artery blood flow might be associated with infertility. Subsequently, other authors have confirmed a relationship between abnormal uterine blood flow and unexplained pregnancy failure (Kurjak et al. 1991 and Steer et al. 1994).

The purpose of this study was to establish a reliable method of obtaining Doppler frequency shift waveforms, from the uterine artery of the mare. An examination of physiological and pathological changes in uterine circulation of mares during the estrous cycle and a comparison of mares with various degrees of endometrosis was then possible. Previous data from other authors have demonstrated that ute- rine blood flow varies regularly during the estrous cycle of cows and sows (Ford et al. 1979; Waite et al. 1990 and Baumgartner 1998). The first investigation of Doppler ultrasound in the mare was carried out by Stolla and Bollwein (1997) and Mayer et al. (1998) who obtained a cyclic pattern in uterine blood flow.

\section{Material and methods}

Ten mares aged between 2 and 20 years were included in the study. Before starting the study the mares were accustomed to the investigation. In order to receive equal conditions all mares were measured daily at the same time and at the same location. Mares were assigned to two groups based on the current classification (Kenney and Doig 1986, modif. by Schoon 1992) of endometrial biopsy. Group A consisted of five mares classified in Category I and Ila. Group B also included five mares assigned to Category llb and III.

All mares were scanned daily during one estrous cycle. The cycle stage was determined daily by gynecological examination and blood samples were taken to analyse serum estrogen and progesterone levels. The examinations were performed using a SONOLINE Versa Pro Colour Doppler 


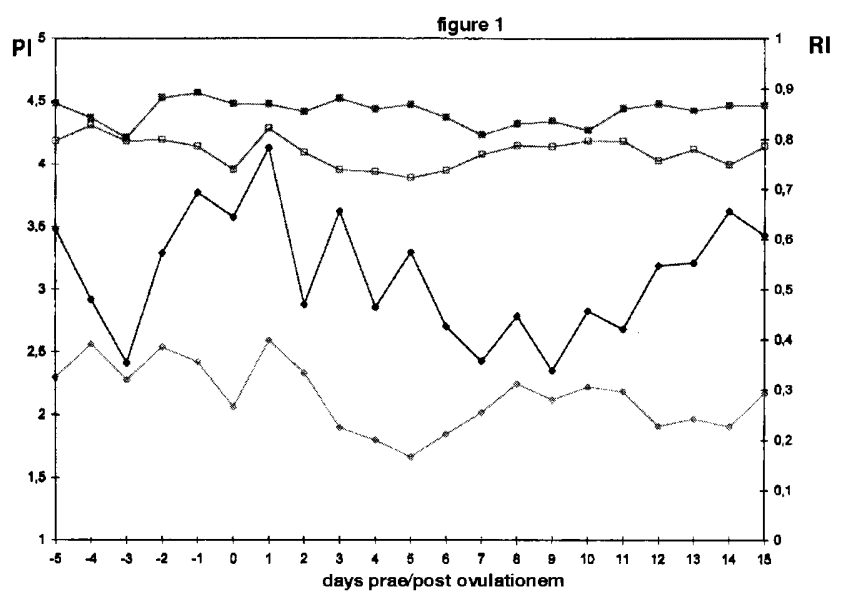

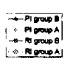

Fig. 1: The diagram shows the pulsatility index $(\mathrm{PI})$ and the resistance index $(\mathrm{R} \mid)$ of the five mares consisted of group $A$ compared to the $\mathrm{Pl}$ and $\mathrm{Rl}$ of the five group $\mathrm{B}$ mares during one estrous cycle (day 0: ovulation). The results are figured as the mean of the corresponding day.

Das Diagramm zeigt den Pulsatilitätsindex $(\mathrm{PI})$ und den Resistance Index der fünf Stuten aus Gruppe A verglichen mit dem PI und dem RI der fünf Stuten der Gruppe $B$ über einen Zyklus (Tag 0: Ovulation). Die Ergebnisse sind als Mittelwerte der entsprechenden Tage dargestellt.

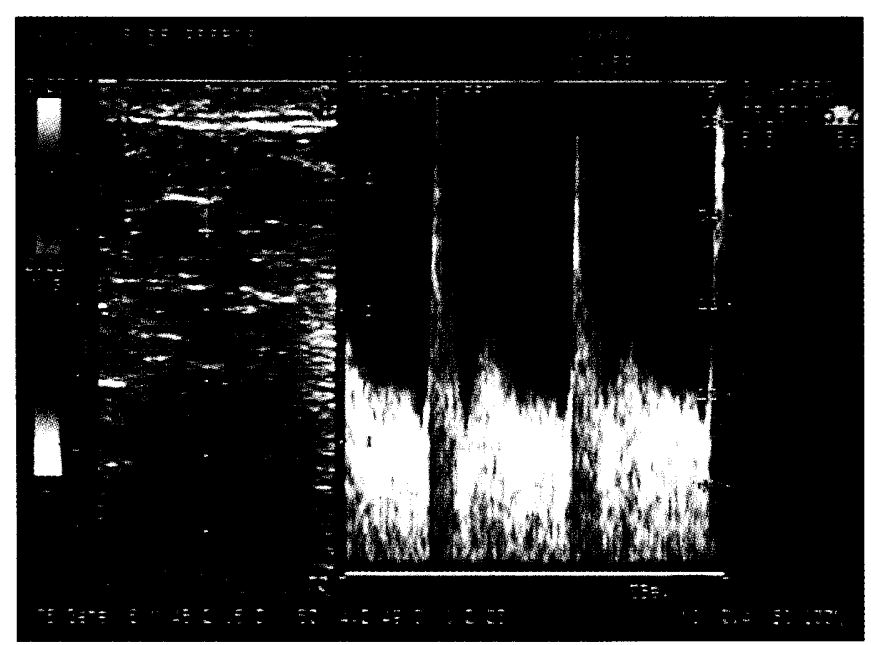

Fig. 2: Typical uterine flow velocity wave form from a group $A$ mare. Left side: Scan of the mesometrium with a cross section of the arteria uterina visualized by colour Doppler as well as the sample volume projected into the vessel. Right side: Doppler flow velocity wave form. A consistent systolic and diastolic flow through to the following cardiac cycle is present. This indicates good uterine perfusion and low impedance.

Typische uterine Dopplerflußkurve einer Stute aus Gruppe A. Links: Sonographische Darstellung des Mesometriums mit einem Querschnitt der mittels Farbdoppler dargestellten Arteria uterina und im Gefäß plazierten Informationsvolumen. Rechts: Dopplerflußkurve. Es besteht ein kontinuierlicher systolischer und diastolischer Fluß bis zur nächsten Herzaktion. Dies bedeutet eine gute uterine Perfusion und einen niedrigen Widerstand.

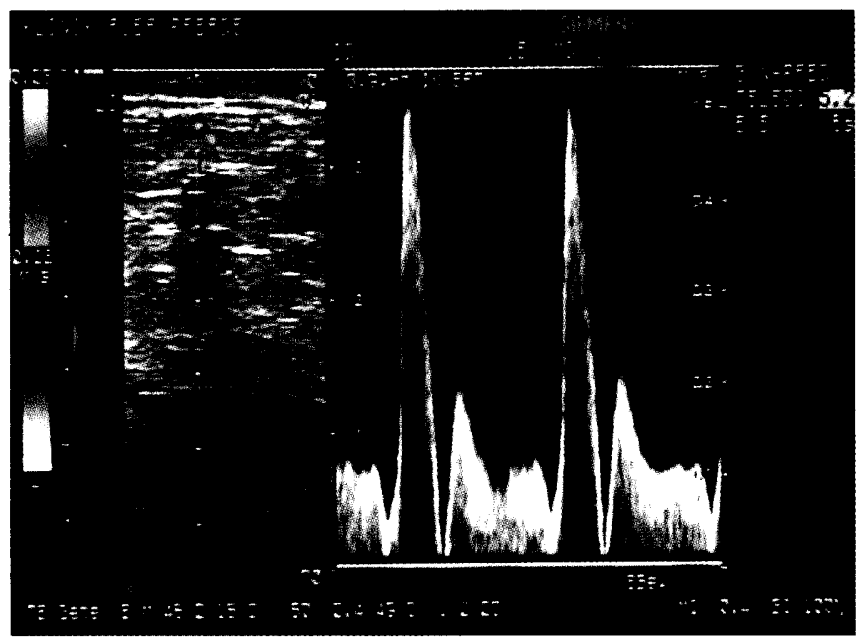

Fig. 3: Uterine flow velocity wave form of a group B mare with high uterine impedance.

Uterine Dopplerflußkurve einer Stute aus Gruppe B mit hohem uterinem Widerstand.

Ultrasonograph (Fa. Siemens). Scanning was performed transrectally using a $7.5 \mathrm{MHz}$ linear probe. Uterine blood flow was measured by examining both arteriae uterinae. The identification of the vessel was carried out by visualizing its branching from the external iliac artery in B-mode ultrasound and following its course in the mesometrium using colour Doppler to the crossing point with the arteria and vena circumflexa ilium profunda. This area was defined as the region of interest and a pulsed Doppler range gate (sample volume) was placed across the vessel. A spectral display of a series of flow velocity waveforms were recorded on videotape and were analysed off-line. Two uniform consecutive waveforms were selected to calculate the resi-

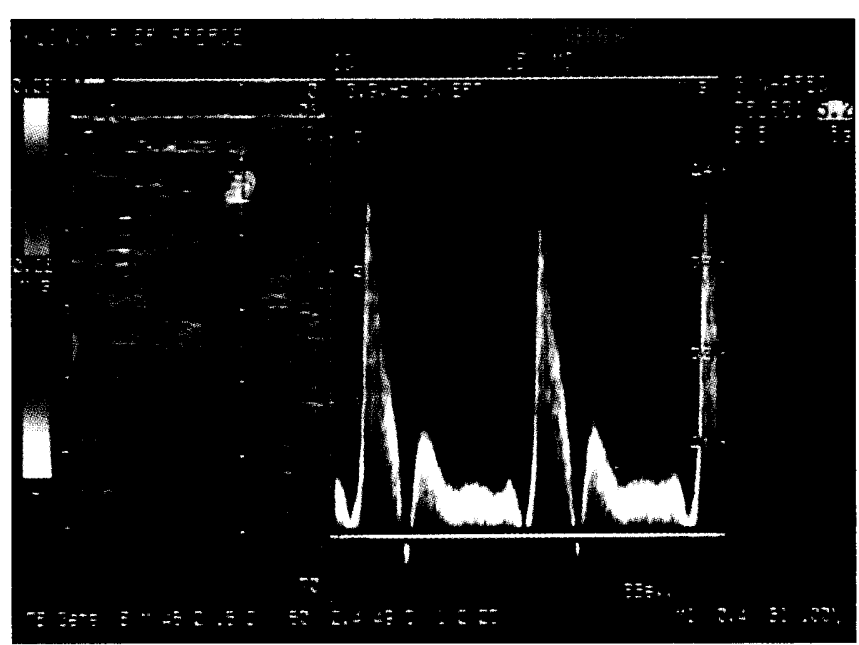

Fig. 4: Uterine flow velocity wave form of a group B mare. Systolic wave form is present, the diastolic wave shows a reversed flow and does not extend to the next cardiac cycle. This indicates a reduced uterine perfusion and high impedance.

Uterine Dopplerflußkurve einer Stute aus Gruppe B. Systolischer Fluß ist vorhanden, die diastolische Flußkurve zeigt einen rückwärtigen Fluß und endet vor dem nächsten Herzzyklus, als Ausdruck einer reduzierten uterinen Perfusion und eines hohen Widerstandes. 
stance index $(R \mid)$ and pulsatility index $(P I)$. Both indices are proportional to the resistance of the vessel distal to the point of sampling and, therefore, give information as to the uterine perfusion (Goswamy and Steptoe 1988 and de Ziegler et al. 1991).

\section{Results}

Blood flow velocity waveforms of the uterine arteries were successfully obtained through colour Doppler imaging in all mares during the estrous cycle. There was no significant difference in the impedance to blood flow between the left and right uterine arteries, which indicates that circulating blood is equally distributed to both sides of the uterus. Therefore, the mean $\mathrm{Rl}$ and $\mathrm{Pl}$ of both sides were used for the calculations. In all mares there was an increase of the vascular resistance in the periovulatory phase and in eight mares the peak occurred one day after ovulation. The impedance of uterine blood flow decreased from day one after ovulation to reach its lowest level during the luteal phase in all mares. There was a gradual increase in the vascular resistance in the early follicular phase. The cyclic changes occurred in all mares with varying amplitude. The alteration in uterine blood flow impedance during one cycle of ten mares is shown in Figure 1.

All of the mares in group $\mathrm{B}$ had a higher median $\mathrm{Pl}$ and $\mathrm{Rl}$ throughout the estrous cycle when compared with the mares of group A, where fertility was assumed to be normal (Figure 1). When comparing the waveforms of both groups only the mares with higher degrees of endometrosis showed absent or reverse diastolic flow, indicating a high resistance in the vascular bed (Figure 2, 3 and 4).

\section{Discussion}

The present study demonstrates that transrectal Doppler ultrasonography in mares is a reliable and consistant method for the detection of changes in uterine blood flow during the estrous cycle. Changes in the flow velocity patterns of the uterine arteries during the normal ovulatory cycle occur in many species: Uterine blood flow reaches a maximum at estrus and is followed by a decrease to a minimum during the luteal phase which has been reported in the ewe, cow and sow (Greiss and Anderson 1969; Ford et al. 1979; Ford and Christenson 1979 and Waite et al. 1990). The use of transrectal Doppler ultrasound in cows not only shows similar results, but additionally a peak resistance on the day after ovulation may be seen (Baumgartner 1998). This postovulatory maximum in uterine impedance could also be seen in the results of this study. In contrast to observations made in other species the results obtained here show uterine blood flow to be lowest, and uterine arterial tone to be highest, in the periovulatory phase, whereas uterine blood flow is highest and uterine arterial tone is lowest

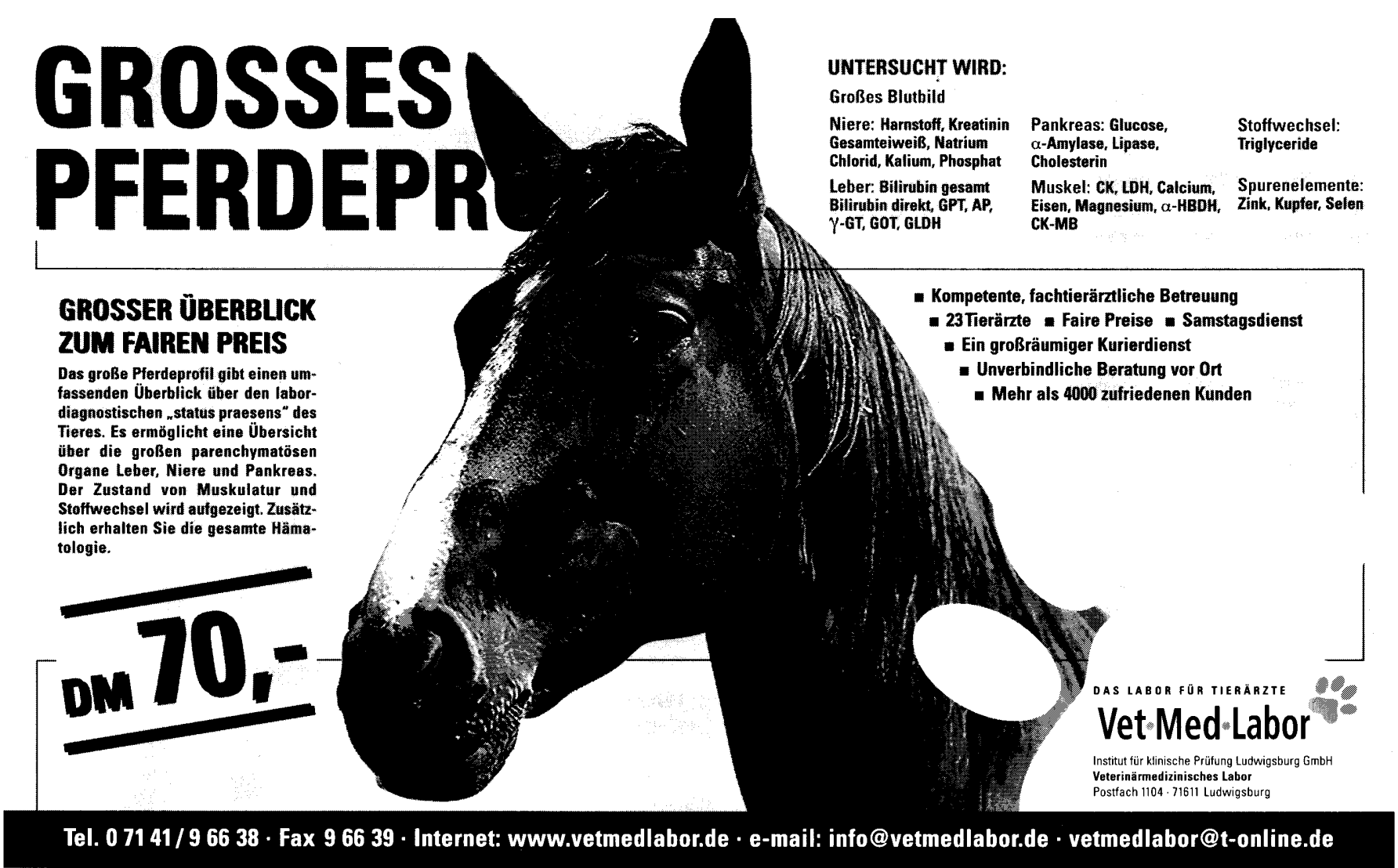


in the luteal phase. These results agree to a large extent, with those previously reported by Mayer et al. (1998) using a similar transrectal Doppler ultrasound technique in the mare. However, they reported a significant decrease in uterine artery impedance in the early follicular phase, which is not evident in this data.

The observation that higher degrees of endometrosis occurs in conjunction with higher uterine impedance, throughout the cycle (Figure 1), concurs with the results of Stolla and Bollwein (1997) and with that of various other authors, who have shown reduced uterine perfusion to cause poor pregnancy outcome and repeated failure of implantation in women (Goswamy et al. 1988; Cacciatore et al. 1996 and Zaidi et al. 1996). The consistent absent or negative diastolic flow in the mares of group B (Figure 3 and 4) agrees with results published by Tekay et al. (1996), where no conception was possible when both uterine arteries had flow velocity waveforms with absent end diastolic flow.

The trends observed in this study support the hypothesis that poor uterine blood flow may contribute to subfertility or even infertility in mares. Work is still in progress to examine relationships between uterine perfusion and plasma steroid levels, the role of estrogen receptors in the vessel walls and also to investigate the presence of unknown vasoactive compounds that may be involved in the regulation of vessels and uterine blood flow.

\section{Literature}

Baumgartner, U. M. (1998): Farbdopplersonographische Untersuchung der Arteria uterina und des Corpus luteum beim Rind. Univ. München, Gynäkologische und Ambulatorische Tierklinik., Diss.

Cacciatore, B., Simberg, N., Fusaro, P. and Titinen, A. (1996): Transvaginal Doppler study of uterine artery blood flow in in vitro fertilzation-embryo transfer cycles. Fertil. Steril., 66, 130-134.

De Ziegler, D., Besses, R. and Frydman, R. (1991): Vascular resistance of uterine arteries: physiological effects of estradiol and progesterone. Fertil. Steril., 55, 775-779.

Ford, S. P. and Christenson, R. K. (1979): Blood flow to uteri of sows during the estrous cycle and early pregnancy: local effect of the conceptus on the uterine blood supply. Biol. Reprod., 21, 617-624.

Ford, S. P., Chenault, J. R. and Echterkamp, S. E. (1979): Uterine blood flow of cows during the oestrous cycle and early pregnancy: effect of the conceptus on the uterine blood supply. J. Reprod. Fertil., 56, 53-62.

Goswamy, R. K. and Steptoe, P. C (1988): Doppler ultrasound studies of the uterine artery in spontaneous ovarian cycles. Hum. Reprod., 3, 721-726.

Goswamy, R. K., Williams, G. and Steptoe, P. C. (1988): Decreased uterine perfusion - a cause of infertility. Hum. Reprod., 3, 955-959.

Greiss, F. C. and Anderson, S. G. (1969): Uterine vascular changes during the ovarian cycle. Am. J. Obstet. Gynecol., 103, 629-640.

Grüninger, B. (1996): Zur Pathogenese von Angiopathien im Endometrium der Stute - Morphologisch-funktionelle Untersuchungen. Univ. Leipzig, Vet.-Med. Fak., Diss.

Kenney, R. M. (1978): Cyclic and pathologic changes of the mare endometrium as detected by biopsy, with a note on early embryonic death. J. Am. Vet. Med. Ass., 172, 241-262.

Kenney, R. M. and Doig, P. A. (1986): Equine endometrial biopsy. In: Current therapie in theriogenology. 2nd edn. Ed.: D. A. Morrow. W. B. Saunders, Philadelphia, p. p. 723-729.
Kriesten, H. (1995): Zur prognostischen Bedeutung von Angiopathien im Rahmen der Kategorisierung von Endometriumsbiopsien bei Stuten. Hannover, Tierärztl. Hochsch., Diss.

Kurjak, A., Kupesik- Urek, S., Schulman, H. and Zalud, I. (1991): Transvaginal color flow Doppler in the assessment of ovarian and uterine blood flow in infertile women. Fertil. Steril., 56, 870-873.

Mayer, R., Bollwein, H. and R. Stolla (1998): Uterine blood flow during the estrous and early pregnancy in mares studied by transrectal colour Doppler sonography. Reprod. Dom. Anim., 33, 71.

Schoon, H.- A-, Schoon, D. and Klug, E. (1992): Uterusbiopsien ais Hilfsmittel für Diagnose und Prognose von Fertilitätsstörungen der Stute. Pferdeheilk., 8, 355-362.

Schoon, D., Schoon, H. A. and Klug, E. (1994): Angiopathien im Endometrium der Stute: Diagnose und prognostische Bedeutung DVG- Tagungsbericht, 13. Arbeitstagung Fachgruppe Pferdekrankheiten, Wiesbaden, 17-29.

Schoon, H.-A., Schoon, D. and Klug, E. (1997): Die Endometriumbiopsie bei der Stute im klinisch-gynäkologischen Kontext. Pferdeheilk., 13, 453-464.

Steer, C. V., Tan, S. L., Mason, B. A. and Campbell, S. (1994): Midluteal phase vaginal color Doppler assessment of uterine artery impedance in a subfertile population. Fertil. Steril., 61, 53-58.

Stolla, R. and Bollwein, H. (1997): Color doppler sonography of the uterine artery in subfertile mares. Pferdeheilk., 13, 547.

Tekay, A., Martikainen, H. and Jouppila, P. (1996): Comparison of uterine blood flow characteristics between spontaneous and stimulated cycles before embryo transfer. Hum. Reprod., 11, 364-368.

Waite, L. R., Ford, S. P., Young, D. F. and Conley, A. J. (1990): Use of ultrasonic Doppler waveforms to estimate changes in uterine artery blood flow and vessel compliance. J. Anim. Sci., 68, 2450-2458.

Zaidi, J., Barber, J. and Kyei-Mensah, A. (1996): Relationship of ovarian stromal blood flow at the baseline ultrasound scan to subsequent follicular response in an in vitro fertilazation program. Obstet. Gynecol., 88, 779-784.

\section{Uta Blaich \\ Svenja Petzold \\ C.P. Bartmann \\ K. Lorber}

Klinik für Pferde

Tierärztliche Hochschule Hannover

Bischofsholer Damm 15

D 30173 Hannover

Tel.: $0511-8567233$

Fax: $0511-8567688$

\section{H.-A. Schoon}

Gerit Raila

Institut für Veterinär-Pathologie

Veterinärmedizinische Fakultät

Universität Leipzig

An den Tierkliniken 33

D 04103 Leipzig

Tel:: $0341-9738270$

Fax: $0341-9738299$

\section{H. Bollwein}

Gynäkologische und Ambulatorische Tierklinik Ludwig-Maximilians-Universität

Veterinärstr. 13

D 80539 München

Tel.: $089-21802612$

Fax: $089-21802161$ 